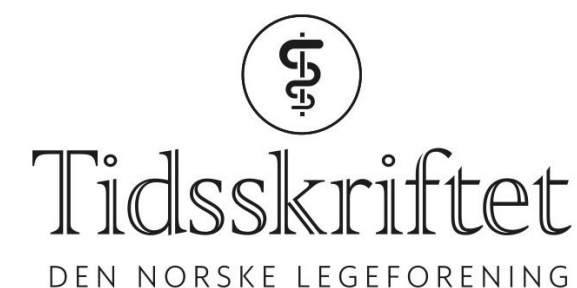

DEN NORSKE LEGEFORENING

\title{
K. Slagstad \& A.K. Lie svarer
}

KOMMENTAR

\section{KETIL SLAGSTAD}

E-post: ketil.slagstad@tidsskriftet.no Ketil Slagstad er medisinsk redaktør. Forfatteren oppgir ingen interessekonflikter.

\section{ANNE KVEIM LIE}

Anne Kveim Lie er førsteamanuensis ved Universitetet i Oslo. Forfatteren oppgir ingen interessekonflikter.

Takk til Bjørn Hofmann for ny kommentar. Slik vi forstår Hofmann i kommentarene til vår lederartikkel har han to anliggender: for det første at enhver diagnostisering av kjønnsinkongruens medfører at normal kjønnsidentitet blir patologisert, og for det andre at medisinsk behandling av kjønninkongruens (hormoner og kirurgi) er problematisk.

Spørsmålet om kjønnsbekreftende behandling burde kunne tilbys uten diagnose, altså å fristille helsetilbudet fra diagnoseapparatet, er interessant og viktig, men det er slik vi ser det del av en mye større diskusjon som også omfatter andre tilbud og tilstander, for eksempel helsetjenester i svangerskapet. Vi tror denne diskusjonen vil føre for langt i et kommentarfelt. Som vi har fremhevet, har det vært diskutert å sette diagnosen «kjønnsinkongruens» i ICDs kapittel over kontakter med helsetjenesten, men man landet på ikke å gjøre dette, siden man var redd for at det kunne føre til at tilbudet til transpersoner ville bli nedprioritert i de enkelte lands heletjenester (1).

Vi er helt enige med Hofmann i at det ville være uheldig og uønsket om det utviklet seg en slags behandlingsstandard som ikke tok hensyn til den enkeltes helsebehov og behandlingspreferanser. Som vi skrev, er det viktig at tilbudet individualiseres, noe som også understrekes i den internasjonale veilederen (2). Noen vil kun ønske hormoner, noen ingen behandling i det hele tatt. Særlig viktig er det at barn og unge fritt får mulighet til å utforske og leve ut egen kjønnsidentitet uten at dette problematiseres eller patologiseres. Samtidig må vi erkjenne at med økt åpenhet og aksept i samfunnet for å stille spørsmål ved egen kjønnsidentitet, kan vi forvente en økning i henvendelser til helsevesenet om rådgivning og behandling (3).

Det er viktig å stille spørsmål, men det er også viktig - og kanskje vanskeligere - å komme med svar. Vi savner Hofmanns standpunkt på hvilket helsetilbud transpersoner skal tilbys. Slik vi leser ham er han skeptisk til all medisinsk kjønnsbekreftende behandling. Det er et standpunkt vi ikke deler. Vi har ikke skrevet at Hofmanns spørsmål er absurde, uinteressante eller uvirkelige, men vi har argumentert for hvorfor vi mener det er søkt å trekke inn «høydeinkongruens», «raseinkongruens», «kroppshårsinkongruens» eller nå «body integrity identity disorder». Hofmann nevner verken disse «tilstandenes» forekomst, 
diagnostikk eller ev. behandling. Slik vi ser det blir dette mer en logisk-prinsipiell diskusjon som ikke opplyser diskusjonen om hvordan leger skal forholde seg til pasienter som ønsker kjønnsbekreftende behandling.

Selv om vi ser tegn i tiden på at samfunnet blir mer åpent og aksepterende for kjønnsuttrykk og seksuell orientering («partner», «hen») er det ikke sikkert at kjønnsdikotomiene har blitt mindre av den grunn. Enten vi vil det eller ei - og uavhengig av hva vi jobber for politisk - er kjønn trolig den mest fundamentale kategorien vi har i samfunnet: Kjønn er det første man spør om etter fødsel («det ble en jente! »), det følger oss gjennom hele barndommen (egne butikkseksjoner for «jente- og gutteleker» og «jente- og gutteklær»), skolegang, ved opptak ved utdanningsinstitusjoner, i Forsvaret, ved jobbsøking osv. - til helt banale gjøremål som å skulle kjøpe flybilletter eller svare på en spørreundersøkelse. Det forklarer trolig noe av det høye lidelsestrykket en del transpersoner opplever på grunn av sin kjønnsdysfori - og den lettelsen det er å kunne passere og bli akseptert som det kjønnet man opplever seg som, enten det er gjennom klær, navn eller medisinske inngrep. Vi mener det er urett og urettferdig å skyve transpersoner foran seg i det viktige arbeidet for et åpnere samfunn med større aksept for ulike kjønnsuttrykk og seksuelle orienteringer, ved å nekte dem tilgang til kjønnsbekreftende behandling, for å forsvare et teoretisk argument om at slik behandling reproduserer kjønnsdikotomier.

Denne diskusjonen er ingen akademisk øvelse; den har kroppslige og psykologiske konsekvenser for personene det gjelder. Det ligger stor makt i å nekte helsetjenester til en marginalisert gruppe, når vi på bakgrunn av den forskningen som foreligger, vet at kjønnsbekreftende behandling reduserer kjønnsdysfori og har dokumenterte positive effekter på livskvalitet og helse $(4,5)$.

\section{LITTERATUR:}

1. Drescher J, Cohen-Kettenis P, Winter S. Minding the body: situating gender identity diagnoses in the ICD-11. Int Rev Psychiatry 2012; 24: 568 - 77. [PubMed][CrossRef]

2. The World Professional Association for Transgender Health. Standards of Care for the Health of Transsexual, Transgender, and Gender Nonconforming People, Version 7. 2011.

https://www.wpath.org/media/cms/Documents/Web\%2oTransfer/SOC/Standards\%20of\%20Care\%2oV7\% 20-\%202011\%20WPATH.pdf(10.8.2018).

3. Gender-affirming care needed for transgender children. Lancet 2018; 391: 2576. [PubMed][CrossRef]

4. Dhejne C, Van Vlerken R, Heylens G et al. Mental health and gender dysphoria: A review of the literature. Int Rev Psychiatry 2016; 28: 44 - 57. [PubMed][CrossRef]

5. White Hughto JM, Reisner SL. A Systematic Review of the Effects of Hormone Therapy on Psychological Functioning and Quality of Life in Transgender Individuals. Transgend Health 2016; 1: 21 -31. [PubMed][CrossRef]

Publisert: 3. september 2018. Tidsskr Nor Legeforen. DOI: 10.4045/tidsskr.18.0629

(C) Tidsskrift for Den norske legeforening 2020. Lastet ned fra tidsskriftet.no 